\title{
Dialética da propriedade fundiária privada no Brasil dos oitocentos
}

\author{
DoSSIER REDE URBANA E DEFINIÇÃO DAS FRONTEIRAS PAULISTAS
}

\section{Dirceu Piccinato Junior}

Doutor em Urbanismo pela Pontifícia Universidade Católica de Campinas [PUC-Campinas]. Arquiteto e Urbanista. Sales Oliveira [SP] Brasil <piccinato.jr@gmail.com>.

\section{Resumo}

O objetivo desta investigação é o de analisar a propriedade fundiária privada, particularmente a urbana, mediante as conjunturas políticas que foram sendo estabelecidas durante o final do período Colonial, no período Imperial e no decorrer da Primeira República. Assim sendo, podemos conjecturar que a dialética da propriedade privada no Brasil durante o século XIX assume processos de ocupação e apropriação territorial como partes integrantes da sistemática de construção e consolidação do Estado brasileiro e da formação das classes sociais do país. O papel desempenhando pela iniciativa privada (ou pública) no tocante à ocupação de terras, bem como à maneira como as políticas governamentais foram adaptando a "questão da terra" em função da pressão exercida pelas camadas predominantes no meio rural e urbano atesta a participação dinâmica da sociedade na definição das posições assumidas pelo Estado relativamente a esta problemática. Como parâmetro de estudo para o presente artigo tomamos como referência a cidade de Ribeirão Preto, interior do estado de São Paulo, e algumas cidades vizinhas a ela.

\section{Palavras-chave}

Propriedade fundiária privada. Terra urbana. Legislações.

\section{Dialectics of private land ownership in Brazil in the nineteenth century}

\begin{abstract}
The objective of this investigation is to analyze the private land property, particularly the urban one, through the political conjunctures that were being established during the end of the Colonial period, in the Imperial period and in the course of the First Republic. Thus, we can conjecture that the dialectic of private property in Brazil during the nineteenth century assumes processes of occupation and territorial appropriation as integral parts of the system of construction and consolidation of the Brazilian State and the formation of the social classes of the country. The role of private (or public) initiative in land tenure, as well as the way in which government policies have been adapting the "land issue" to the pressure exerted by the predominant layers in rural and urban environments, Society in defining the positions taken by the State regarding this problem. As a parameter of study for the present article we take as reference the city of Ribeirão Preto, in the interior of the state of São Paulo, and some cities neighboring it.
\end{abstract}

\section{Keywords}

Private land ownership. Urban land. Legislation. 


\section{Introdução}

O período Colonial no Brasil se estendeu desde o seu descobrimento (1500) até a chegada da família Real portuguesa no ano de 1808. Foram pouco mais de 300 anos de relação política, econômica e social entre Brasil e Portugal. Estes três séculos de relação direta e em determinados momentos conflituosas entre metrópole e colônia definiu o caráter do Estado brasileiro. Neste sentido, são muitas as pesquisas na área de história, história do urbanismo e da arquitetura que contemplam as diferentes realidades e contextos regionais do Brasil na tentativa de se construir as histórias nacionais.

Todavia, o caráter mais significativo do período Colonial reside na forma pela qual se distribuiu a terra. A superfície do solo e seus recursos naturais constituíam, naturalmente, a principal riqueza da colônia. O Brasil colônia possuía uma só riqueza: seus recursos naturais; consequentemente, empregou-se uma forma de exploração: a agricultura ou a pecuária, ambas subordinadas à posse fundiária.

Os forais dos donatários determinavam que as terras deveriam ser distribuídas em sesmarias aos moradores. Ficava, conquanto, a apropriação da terra sob regulações jurídicas, já que a designação sesmaria não se referia genericamente a qualquer forma de doação, mas, pelo contrário, subordinava-se as normas jurídicas.

Ainda neste momento histórico as câmaras municipais representavam e constituíam-se a verdadeira e quase única administração da colônia. Em certa medida, a administração municipal nasce como resultado da influência rural. Elas são dominadas pelos proprietários rurais. Nas eleições para os cargos da administração municipal só podiam votar os homens bons. 0 poder das câmaras é o poder dos proprietários rurais e seu raio de ação é amplo, maior do que era estabelecido nas Ordenações reinóis.

O Brasil colonial forma uma unidade somente no nome. Na realidade ele foi um conjunto de órgãos independentes, unidos entre si apenas pelo domínio comum, muito em razão das diferentes realidades que se constituíram no país.

Em razão deste lastro temporal de influência do período colonial brasileiro, o século XIX, em diversos momentos, foi visto como um entreposto entre as dimensões históricas colonial e republicana nacional, ou seja, o período Imperial ainda merece análises e investigações mais profundas na tentativa de esclarecer esse momento histórico brasileiro em que as indefinições políticas, econômicas e sociais possibilitaram na construção da ordem e do Estado.

A transferência da Corte portuguesa para o Brasil em 1808 representou a nossa emancipação política e conferiu um caráter singular ao processo histórico de independência. Enquanto nas demais colônias americanas o processo de independência aconteceu no campo de batalha, no Brasil, o próprio governo metropolitano, em razão das circunstâncias europeias, foi quem determinou as bases da autonomia nacional.

Com a chegada da família Real observamos que o poder se centralizou na cidade do Rio de Janeiro, que gradativamente foi impondo a unidade ao país. Na visão de algumas capitanias, depois províncias, o Rio de Janeiro apenas substituiu Lisboa. Os impostos recolhidos não revertiam as capitanias, tinha um destino certo: a cidade carioca; onde custeariam as despesas da corte e do governo central.

Em 1822 o Brasil torna-se independente. Nos dois primeiros anos após a Independência, o debate político se concentrou no problema da aprovação de uma Constituinte. A Constituição de 1824 vigorou com algumas modificações até o fim do Império. Ela definiu o governo como monárquico, hereditário e constitucional. Nesta constituição nada foi dito sobre a terra 0 Império brasileiro teria uma nobreza, mas não uma aristocracia, ou seja, existiriam nobres por títulos concedidos pelo imperador, mas esses títulos não seriam hereditários. A religião católica apostólica romana continuava a ser religião oficial, permitindo-se apenas o culto particular de outras religiões.

O país foi dividido em províncias cujos presidentes seriam nomeados pelo imperador. Asseguraram-se neste momento da história os direitos individuais, entre eles a igualdade perante a lei, a liberdade de religião e a liberdade de pensamento e manifestação. 
Assim sendo, o Reino nacional entrava num momento de prosperidade, propícia à consolidação do processo de formação do Estado brasileiro. Esta prosperidade estava associada à expansão da cafeicultura na região centro-sul do país.

A expansão do café da primeira metade do século XIX teve repercussões imediatas e decisivas na questão da apropriação territorial. Os fatores singulares para os desdobramentos da questão da terra após 1840 foram de duas ordens: de um lado, a localização do novo ciclo econômico; de outro, as bases em que se estruturou toda a atividade cafeeira particularmente a disponibilidade de terras.

A referência à disponibilidade de terras como fator básico no sistema econômico que girava em torno da cafeicultura obrigava os proprietários rurais a reafirmar mais uma vez a importância da manutenção do trabalho escravo, que viabilizava a disponibilidade de terra que existia para o senhorio rural.

Para o senhorio rural não se colocava com urgência a questão da regularização da propriedade da terra enquanto o antigo sistema produtivo colonial (trabalho escravo e a apropriação livre das terras) pudesse se manter. 0 desenvolvimento da economia cafeeira que começava a alterar a feição nacional, em muitos aspectos, não alterou esse quadro. Estava centrado no tráfico e no trabalho escravo, e na possibilidade de incorporação contínua de novas terras. Os ajustamentos e compromissos que sustentavam essa situação protelavam a adoção de medidas modernizadoras que adaptassem a sociedade aos novos tempos em que o capitalismo começava a ampliar sua atuação, ou seja, alcançando escala internacional. Conquanto, em 1850, essa situação se altera, em grande parte por pressão externa.

A extinção do tráfico de negros e a implantação da Lei de Terras (1850) foram duas medidas importantes que buscou alterar a fisionomia do país, encaminhando-o para o que se chamava modernidade. A Lei de Terras procurou regulamentar a confusão existente em matéria de propriedade rural, determinando que, no futuro, as terras públicas fossem vendidas e não doadas, como aconteceu com as antigas sesmarias, estabeleceu normas para legalizar a posse da terra e instituiu o registro de propriedade.

O caráter morfológico da propriedade fundiária, rural e urbana, foi significativamente alterado. Pelas brechas das indefinições políticas e normativas o que se observou foi um rearranjo fundiário em que o fomento capitalista (re)configurou a propriedade privada.

Assim, advogamos nesta investigação ${ }^{1}$ que a instabilidade política, econômica e social pelo qual passava o país nos anos oitocentos foi fundamental para o rearranjo do poder e da propriedade fundiária, particularmente a urbana. 0 intuito de quem estava no poder era o de manter-se nele e aqueles que haviam adquiridos ou conquistados oportunidades e bens era o de resguardar seus respectivos privilégios. Para tanto, a configuração da terra ganha aspectos racionais em seu desenho, em razão da possibilidade de se lucrar com o mercado fundiário em formação.

\section{Breves considerações sobre política, economia e sociedade do Brasil do século XIX}

No ano de 1808, de um dia para outro, a cidade do Rio de Janeiro tornou-se na capital portuguesa. Com a chegada da família imperial tiveram que ser estruturadas as instituições estatais metropolitanas. Foi necessário (re)montar o Estado, que literalmente tinha vindo de navios, incompleto e em partes. Transplantou-se para o Brasil o antigo Regime. Assim sendo, a partir de 1808, o país ganha novas feições: o poder passou a centralizar-se no Rio de janeiro, que de certo modo foi construindo uma unidade ao país.

No período colonial o espaço urbano é elemento geográfico de apoio à formação territorial. Durante este momento histórico e parte do século XIX a forma geral como inicialmente surge um espaço

\footnotetext{
10 presente trabalho origina-se de nossa tese de doutorado intitulada "Em chão urbano, o senhorio é santo: urbanização e aforamento de terras no Bispado do Ribeirão Preto entre o Brasil Império e a Primeira República”, defendida em dezembro de 2016 nas dependências da Pontifícia Universidade Católica de Campinas, Programa de Pós-Graduação em Urbanismo, sob a orientação da Prof.- Dr.- Ivone Salgado.
} 
urbano é através da formação de um pequeno aglomerado, comumente uma rua e algumas moradias de maneira que esta povoação passa a ganhar com o tempo mais corpo e complexidade estrutural. A intervenção da Coroa portuguesa busca no decorrer do tempo distingui-lo segundo sua dimensão e papel administrativo.

Uma vez esta localidade alcançando a condição de vila, a presença dentro dela de uma Câmara é parte fundamental de sua formação. Esta é na verdade um prédio rústico em forma de sobrado que reúne as funções simultâneas da administração, da representação política e da prisão da cidade, distinguindo-se dos demais prédios basicamente por estas funções, "numa importância só disputada pela presença e papel do prédio da Igreja" (Moreira, 2014, p. 79), conquanto, é a Igreja o centro de referência do urbanismo.

Após a independência do Brasil em relação a Portugal (1822), a presença das Câmaras Municipais foi marcante. Não houve episódios notáveis em que as Câmaras não tenham tomado atitudes decisivas em relação aos problemas que se apresentavam. Podemos considerar que elas representavam, como órgãos políticos, a nação.

Segundo Brasil Bandecchi, o governo econômico dos municípios residia nas Câmaras, instituídas em todos os povoados onde o exigisse o bem público. As Câmaras eram compostas de vereadores, cujo número variava conforme a lei local, de um procurador e um escrivão. Os vereadores e o procurador eram eleitos anualmente. 0 vereador que obtivesse maior número de votos seria o presidente da Câmara Municipal. 0 escrivão era nomeado pela Câmara. Os vereadores não podiam ser reeleitos para o mandato seguinte ao que haviam servido; deviam ter mais de 25 anos e residir há pelo menos dois anos no Concelho, além de terem meios lícitos de subsistência e não ocuparem cargos incompatíveis com o exercício da vereança. Competia à casa dos vereadores, durante o Império, fazer proposituras ou leis municipais; promover a agricultura, o comércio, a indústria, a saúde pública; propor feiras e mercados nos lugares mais convenientes com a aprovação da junta administrativa; cuidar das escolas de primeiras letras e outros estabelecimentos de educação pagos pelos rendimentos públicos, bem como hospitais e casas de beneficência; zelar pelas obras particulares do Concelho e do reparo das públicas, promover a plantação de árvores nos terrenos baldios e nas terras do Concelho; repartir a contribuição direta pelos moradores do Concelho e fiscalizar a cobrança e remessa dos rendimentos; cobrar e dispender os rendimentos do Concelho (Bandecchi, 1972, p. 57-58).

Como a atenção do Império se voltava exclusivamente para as questões administrativas municipais, a sistemática de fundação e elevação de status urbanos continuavam parcimoniosas e remanesciam muitas das condições do período colonial. Victor Nunes Leal pondera que, uma vez passado o período áureo das câmaras coloniais, sobrevieram a "inexpressiva" interferência régia e a tutela imperial (Leal, 2012, p.68). Tal fato nos faz considerar que a configuração e a estrutura morfológica dos espaços urbanos ainda se baseavam em capelas, freguesias, vilas e cidades; status urbanos característicos do período Colonial brasileiro.

Analisando as Leis do Império, observamos a preocupação das autoridades da época com o processo de criação de vilas, possivelmente por, nessa instância, o poder civil se fazer efetivamente presente no espaço urbano. No decreto de 13 de novembro de 1832, foi estabelecida a maneira de se fazer efetiva a criação de uma vila. A referida deliberação argumentou que, para tal propósito, deveria ser emitido um "Decreto da sua creação", no qual seriam designados os limites do seu termo junto à Câmara Municipal, à qual passava a pertencer a nova vila. Ao juiz de paz do novo termo caberia proceder à eleição dos vereadores. Depois das eleições, deveria ser realizada a apuração e, conhecidos os vereadores eleitos, realizar-se-ia uma reunião em dia e local especificados na nova vila, comunicando a todos por escrito em editais públicos. O Presidente da Câmara Municipal deveria comparecer com um secretário no dia e lugar fixados e, reunidos os vereadores, seriam feitos o juramento e a concessão da posse aos mesmos. Depois dessas formalidades lavrar-se-ia o auto da instalação. A nova Câmara nomearia seus oficiais e demais empregados, ordenaria a arrecadação das contribuições municipais de seu termo, que anteriormente pertenciam à Câmara ou Câmaras de que fora desmembrada a nova vila, remetendo à província cópia dos fatos².

2 Coleções das Leis do Império: Decreto de 13 de novembro de 1832.

(C) Labor \& Engenho, Campinas [SP] Brasil, v.11, n.3, p.335-354, jul./set. 2017. 
No ano de 1833, esse decreto acima analisado foi alterado e um novo foi promulgado, dando ênfase à maneira como seriam instaladas as Câmaras Municipais nas novas vilas. 0 decreto de 22 de julho de 1833 apontava que, considerando, por experiência, que o Presidente da Câmara e o secretário nem sempre podiam comparecer de imediato ao lugar da nova vila para deferir juramento de posse aos novos vereadores, em razão das distâncias entre elas, a Regência ordenava que o Conselho Administrativo de qualquer província, reconhecendo excessiva a distância da vila criada, faria com que o Presidente expedisse as ordens necessárias para que o vereador mais votado para a nova vila, que teria de servir como Presidente da Câmara, prestasse juramento por seu procurador na Câmara Municipal do respectivo termo. Deveria este convocar os demais vereadores, mediante o juramento, para instalar a Câmara Municipal conforme o decreto 3 .

Tanto o decreto de 1832 como o de 1833 demonstraram preocupações com a administração da vila. Há, todavia, um dado que nos chama a atenção: a falta de menção à demarcação do rossio, circunscrição territorial de grande importância quando da criação de uma vila. Até então, as cidades haviam sido fundadas sobre patrimônios religiosos; quando eram elevadas à condição de vila, a demarcação do rossio representava o domínio do poder civil sobre o religioso, já que a demarcação civil se sobrepunha à religiosa, situação que gerou diversos conflitos acerca da posse da terra urbana entre as Câmaras Municipais e a Igreja em muitas localidades. Para nós, uma substancial mudança para a condição da terra urbana ocorreu quando a legislação passou a permitir que as autoridades deixassem de especificar o processo de definição do rossio. Nas primeiras décadas do século XIX, a tradição de doar um patrimônio religioso a um santo de devoção, quando da formação de uma capela, continuou como tradição na formação dos novos povoados. Uma vez formado o patrimônio de um santo de devoção, mesmo com os sinais dos ideais republicanos que acenavam timidamente, a terra urbana permaneceria sob a tutela da igreja, independentemente do que viesse a acontecer.

Ainda hoje, em um número considerável de cidades brasileiras o patrimônio religioso original de fundação da vila possui a Igreja como titular direta da terra e em regime de aforamento ${ }^{4}$, como é o caso de cidades na região em destaque neste trabalho, a região de Ribeirão Preto.

O ano de 1850 é um divisor de águas na vida política e social do Império. 0 fim do tráfico ilegal de africanos interrompeu o principal fluxo de mão de obra para a cafeicultura fluminense e paulista, o que obrigou o governo imperial a imaginar alternativas para a sua substituição.

A Lei de Terras de 1850 foi formulada com o objetivo de regular a venda de terras públicas para fins de desenvolvimento agrícola. As terras públicas urbanas não estavam na pauta das novas políticas fundiárias e essa ausência de definições sobre a questão da terra urbana estará na origem de muitos conflitos relativos às terras do patrimônio religioso que ficaram sob o regime de aforamento.

Todavia, foram as ferrovias que provocaram significativos impactos na vida econômica, política, social e cultural sob diversos aspectos: provocaram a unificação do mercado interno, facilitando a circulação de pessoas e mercadorias; baratearam o custo do transporte, favorecendo as exportações; permitiram a expansão da fronteira agropecuária e mineradora; induziram a expansão do setor de produção de aço, máquinas e ferramentas, equipamentos ferroviários, construção civil e ferroviária; estruturaram e consolidaram a formação do saber erudito de profissionais do setor industrial.

A intensificação do processo de urbanização desta região (de Ribeirão Preto) se deu com o avanço das culturas do café que começava a se implantar em uma nova zona, no interior do estado de São Paulo, chamado na época como Oeste Paulista. Nas referências históricas, essa região não corresponde rigorosamente ao oeste geográfico. Ela abrange a área que vai de Campinas a Rio Claro, São Carlos, Araraquara, Catanduva, no percurso da linha férrea paulista; e de Campinas para Pirassununga, Casa Branca e Ribeirão Preto, pela Estrada de Ferro Mogiana.

\footnotetext{
${ }^{3}$ Coleções das Leis do Império: Decreto de 22 de julho de 1833.

4 Aforamento, enfiteuse ou emprazamento são sinônimos de um procedimento jurídico que, ao longo do tempo, mostrou-se bastante flexível em relação ao momento histórico, aos interesses dos diversos agentes sociais e à sua adequação ao meio social. A enfiteuse, de maneira geral, expressa uma propriedade compartilhada entre o senhorio, aquele que detém a posse legal da terra, e o enfiteuta, o indivíduo que possui apenas o direito de usufruir do bem.
} 
Quanto as questões do município, incontestavelmente, durante todo o regime Imperial, a vida municipal brasileira procurou a autonomia perdida de forma articulada a partir do final dos anos vinte dos oitocentos. A partir de então, mesmo com algumas tentativas aqui e ali, essa autonomia dificilmente encontrava um ponto de apoio em que pudesse se fundamentar e que lhe servisse de defesa. A primeira Constituição do Império deixou caminho aberto para que se desse ao município nacional o lugar político-administrativo que, por direito e por tradição, era de sua competência. As leis posteriores, sob aspectos básicos, não fizeram mais do que embaraçar e confundir competências (Bandecchi, 197, p. 95-96).

O cenário que então se abria era adequado a todo tipo de pensamento, projetos e utopias. A República surgiu no Brasil proclamando promessas de igualdade e de cidadania; ela era uma modernidade que se impunha menos como opção e mais como uma etapa obrigatória. Os anos da Primeira República (1889-1930) foram anos de incertezas. Os grupos que disputavam o poder tinham interesses distintos e divergiam na concepção de como organizar a República.

A real condição do Brasil na Primeira República não foi a expressividade do dinamismo da urbanização, mas o complexo diálogo entre os "diferentes Brasis" que eram, na verdade, um só: aquele que era palco dos choques entre populações com costumes diversos e, sobretudo, as novas ilusões do progresso e da modernidade. Para Lilia Moritz Schwarcz, "modernização e tradição eram conceitos fortes nesse momento que previa mudanças, mas experimentava continuidades de toda ordem" (Schwarcz, 2012, p. 41).

\section{A dialética da propriedade da terra no Brasil}

A palavra sesmaria significa a sexta parte, porém o termo sesmaria acabou assumindo no Brasil a característica genérica de terra doada, com vistas ao cultivo. No Brasil, o regime sesmarial foi implantado conjuntamente com as capitanias hereditárias, definindo um padrão que marcou a estrutura fundiária nacional sob a forma do latifúndio. Para João Antônio de Paula, as sesmarias eram distribuídas por meio de um modelo mínimo, que era a légua quadrada, isto é, 6,6 mil metros quadrados; a estrutura desse instituto não foi homogênea, pois contemplou desde "impérios territoriais", como a sesmaria da Casa Garcia d'Ávila, que ficava às margens do rio São Francisco, até sesmarias menores de uma légua quadrada (Paula, 2012, p. 196).

Márcia Maria Menendes Motta chama a atenção para o fato de que a concessão de terras ociosas para o cultivo pelo sistema de sesmaria era, antes de tudo, uma concessão política, e não necessariamente territorial. A concessão, ao expressar o poder daquele que concede, no caso a Coroa portuguesa, impunha a submissão dos que recebiam, na crença de um Estado que se fundamentava na hierarquia de toda a sociedade. A sesmaria era o instrumento da colonização e, nesse sentido, um instrumento de poder (Motta, 2012, p. 122).

A motivação essencial das Leis de Sesmarias era o cultivo da terra. Uma sesmaria improdutiva deveria ser dividida de tal maneira que toda ela produzisse riqueza. No entanto, esse princípio, pelo que revela a historiografia, nunca foi exatamente cumprido, resultando da prerrogativa os grandes latifúndios. É notório, como escreve João Antônio de Paula, que o regimento do Governador-Geral Tomé de Souza, de 1548, que mandava distribuir as terras em sesmarias - mas condicionando a distribuição aos que possuíssem condições financeiras suficientes para a construção de casas-fortes, o que está na base da constituição da estrutura fundiária concentrada -, foi o ponto de partida para a estruturação e conformação do poder oligárquico, fenômeno fundamental para a vida política e cultural que veio a se configurar na Primeira República: o coronelismo (Paula, 2012, p. 196).

Tantas foram as liberalidades nas concessões de sesmarias, com áreas de dez, vinte e até cem léguas, com diversas doações a um mesmo requerente, que, em 1822, não havia mais terra a ser distribuída. As terras estavam de certo modo quase todas repartidas. Portanto, estava o quadro definido: a grande propriedade havia tomado conta do país, com a dependência e o bloqueio de ascensão do lavrador à condição de proprietário. A sesmaria não atingiu o seu objetivo de cultivo e aproveitamento, mas imobilizou o status do senhor de terras, menos em proveito da produção agrícola do que da expansão territorial. Assim, o fim do regime sesmarial era inevitável devido à 
exaustão dos bens a distribuir. A partir desse momento, em lugar dos favores do poder público, a terra seria adquirida por herança, doação, compra e, sobretudo, pela posse, transmissível por sucessão e alienável pela venda e compra (Faoro, 2012, p. 464-465).

O regime sesmarial, da maneira como se desenvolveu no Brasil, não deve ser analisado de modo uniforme em todas as regiões. A posse de grandes áreas, provavelmente, teve um peso menor quando se considera, por exemplo, a economia mineradora das Minas Gerais. 0 que devemos evitar é uma generalização que atribua homogeneidade a um quadro histórico-espacial marcado pela diversidade socioterritorial.

O braço do trabalho durante o Brasil Império foi o escravo. A partir dos anos de 1840, quando o mercado brasileiro se encontrava abastecido de escravos africanos, iniciaram-se algumas medidas efetivas de combate ao tráfico; a escravidão estava destinada a acabar.

Mediante as ameaças ao sistema de escravidão, a solução encontrada para a falta de braços na lavoura, desde a primeira década do século XIX, foi a implantação de núcleos coloniais. A propriedade fundiária brasileira ganhava mais um capítulo em sua história. A estratégia do governo nacional consistia na contratação de trabalhadores assalariados europeus, e a maneira encontrada de permanecerem no país seria através da distribuição de pequenas propriedades de terras. Os núcleos coloniais atuariam como agentes idealizadores de futuras cidades, já que havia necessidade de povoamento e estruturação social do país, por intermédio de uma classe média que deveria ser formada por um novo elemento nacional, diferente do negro. Neste sentido, os núcleos coloniais viabilizavam a vinda dos imigrantes europeus que viriam a formar a sociedade brasileira.

O núcleo colonial Antônio Prado foi criado no ano de 1887 no município de Ribeirão Preto. Assim como os demais núcleos fundados no Brasil, o núcleo Antônio Prado buscava abrigar os trabalhadores europeus trazidos para lavoura, particularmente, a cafeeira e sendo distribuídos em pequenas propriedades. Para Adriana Capretz Borges da Silva, quando analisou o núcleo colonial Antônio Prado em Ribeirão Preto, entre a constatação de não ser mais possível a manutenção do regime escravocrata e a passagem para o trabalho livre e assalariado, houve um período de coexistência de vários sistemas de emprego de mão de obra juntamente com a escravidão, o que levava a muitos proprietários continuarem a tratar os trabalhadores como escravos (Silva, 2008b, p. 47).

Boris Fausto argumenta que o fim da política de sesmaria foi a elaboração e promulgação da Lei de Terras após a extinção do tráfico. Para o autor, a lei, além de tentar pôr ordem na comercialização de terras públicas, foi também uma forma de evitar o acesso à propriedade da terra por parte de futuros imigrantes. Ela estabelecia, por exemplo, que as terras públicas deveriam ser vendidas por um preço suficientemente elevado para afastar posseiros e imigrantes pobres. Estrangeiros que estavam no país mediante passagens financiadas foram proibidos de adquirir terras antes que se completassem três anos de sua chegada. Em síntese, os grandes fazendeiros queriam atrair imigrantes para começar o processo de substituição da mão de obra escrava, tratando de evitar que logo se tornassem proprietários de terras. Todavia, a grande massa de imigrantes estava ainda distante de nossa realidade. Assim, a opção utilizada pelos fazendeiros das áreas de produção agrícola foi abastecer-se de escravos no mercado interno, comprando-os nas regiões em decadência (Fausto, 2015, p. 169).

A Lei de Terras de 1850 tinha, entre tantos outros objetivos, a viabilização da implantação dos núcleos coloniais, por intermédio da demarcação das terras realmente cultivadas e disponibilizadas daquelas incultas (as "devolutas") para a formação dos núcleos coloniais, bem como converteria a terra em capital, substituindo a garantia de crédito hipotecado que o escravo representava ao fazendeiro, uma vez que a abolição se aproximava. Com a terra capitalizada, o acesso seria permitido apenas aos que dispunham de meios de obtê-la, consolidando de vez a posse apenas por parte de uma elite latifundiária. Entretanto, utilizando-se todo tipo de fraudes nos registros oficiais, os fazendeiros cafeicultores (especialmente os paulistas) trataram logo de comprovar a posse das melhores áreas, e as terras devolutas que seriam destinadas à criação dos núcleos coloniais foram escassas, em terras pouco produtivas, distantes dos centros urbanos (Silva, 2008b, p. 49).

Ligia Osorio Silva analisa o contexto sobre o fim das Leis de Sesmarias e afirma que o ocaso do regime de sesmarias confunde-se com o processo de emancipação da Colônia. Para a autora, a suspensão 
do regime de concessão de sesmarias, no ano de 1822, quase que simultaneamente à declaração de independência, não pode ser visto como uma coincidência. As contradições entre o senhoriato rural da Colônia brasileira e a metrópole portuguesa contribuíram também para a ruptura definitiva dos vínculos amalgamados durante pouco mais de dois séculos (Silva, 2008a, p. 85).

A Lei no 601 de 18 de setembro de 1850, ou a comumente chamada Lei de Terras de 1850, dispõe sobre as terras devolutas do Império. Ela é composta de dezoito artigos e vários incisos sobre as terras que foram possuídas por título de sesmaria sem preenchimento das condições legais, bem como pelo simples título de posse mansa e pacífica. Essa lei determinou que, medidas e demarcadas as primeiras sesmarias, seriam elas cedidas a título oneroso, tanto para empresas, como para o estabelecimento de colônias nacionais e de estrangeiros, autorizando o Governo Imperial a promover a colonização estrangeira na forma que se declara na referida legislação. Essa legislação estabeleceu normas e cuidados com a terra rural, deixando a terra urbana sob os cuidados das igrejas e câmaras municipais.

O Art. $1^{\text {o }}$ deixa claro que, a partir daquela data, as aquisições de terras devolutas só poderiam ser realizadas a partir do título de compra. Sobre o que ficou entendido por terras devolutas, a lei esclarece que todas as terras que não se acharem sob o uso público nacional, provincial ou municipal; as terras que não se acharem no domínio particular por qualquer título legítimo, nem forem adquiridas por título de sesmarias ou outras concessões do Governo-Geral ou Provincial; as terras que, mesmo "incursas em comisso", forem revalidadas pela própria lei; por fim, as que não se acharem ocupadas por posses que, mesmo que não se enquadrem em título legal, podem ser legitimadas por esta lei5.

O sentido original de "devoluto" era aquele de terra concedida, que, pelo fato de o concessionário não preencher as condições da concessão, voltava ao senhor original, ou seja, à Coroa. Ligia Osorio Silva complementa a definição relatando que terras devolutas são aquelas que não estão incorporadas nem ao patrimônio público, nem ao particular e muito menos ao patrimônio religioso urbano. Para tanto, o espírito da lei, ao identificar terra devoluta com terra inculta, era ainda o de estimular o cultivo e respeitar todo aquele que efetivamente a cultivava (Silva, 2008a, p. 173-175).

Diferentemente de Portugal, que no século de XIX procurou desvincular a terra de qualquer organização social de outrora, a lei brasileira buscou legitimar a posse das antigas ocupações, fossem elas civis ou religiosas, já que não distinguiu as instâncias, bem como das dadas em título de sesmaria. A lei preocupou-se com a estruturação fundiária a partir desses anos de 1850. Mesmo que estudos de casos revelem que ela não foi aplicada de imediato, ela foi fundamental para o rearranjo fundiário que aconteceria nos anos de desenvolvimento e expansão da frente pioneira do café, especialmente no estado de São Paulo.

Quando tentamos identificar artigo ou inciso em que a lei tenha redirecionado o processo da espacialização urbana, observamos, no $\S 4^{\circ} \mathrm{O}$ do Art. 5ํㅡㄹ a legitimação das posses mansas e pacíficas, adquiridas por ocupação primária e que se encontrassem cultivadas ou com "princípio de cultura e moradia"; observamos ainda que os campos de uso comum dos moradores (rossio) de uma ou mais "freguesias, municípios ou comarcas serão conservados em toda a extensão de suas divisas", e continuariam a prestar o mesmo uso, conforme a prática que vigora atualmenté. Tal colocação nos faz pensar que a estruturação e delimitação territorial da sistemática "parcimoniosa" da configuração urbana não tenha sofrido consideráveis alterações.

Outros dois, o Art. 12 e o Art. 13, referem-se à terra urbana. 0 primeiro revela que o Governo preservaria terras devolutas que julgasse necessárias para colonização indígena, a fundação de povoações, abertura de estradas e quaisquer outras servidões e assento de estabelecimentos públicos e construção naval. 0 segundo artigo propõe a organização por "freguesias o registro das terras possuídas"7.

\footnotetext{
${ }_{5}^{5}$ Lei de Terras de 1850. Disponível em: <http://www.planalto.gov.br/ccivil_03/Leis/L0601-1850.htm>; Acesso em: 21 fev. 2017.

${ }^{6}$ Lei de Terras de 1850. Disponível em: <http://www.planalto.gov.br/ccivil_03/Leis/L0601-1850.htm>; Acesso em: 21 fev. 2017.

${ }^{7}$ Lei de Terras de 1850. Disponível em: <http://www.planalto.gov.br/ccivil_03/Leis/L0601-1850.htm>; Acesso em: 21 fev. 2017.
} 
Durante os períodos Colonial, Imperial e parte do Republicano destacou-se um processo, se não o mais comum, foi sem dúvida o mais difundido em terras paulistas que consistia na doação de terras feita por um morador, ou um conjunto dele, para a formação do patrimônio fundiário urbano de um santo de devoção. Neste patrimônio religioso, através do aforamento da terra urbana, a localidade ganhava destaque e status urbanos, tais como: povoado, arraial, capela, freguesia, vila e, por fim, cidade. Esta tendência geral de configuração do espaço urbano apresentava uma sistemática muito particular quanto à posse da terra. Todavia, a pesquisadora Adriana Capretz Borges da Silva levanta uma hipótese que precisa ser melhor esclarecida sobre a terra urbana neste momento de importantes transformações ocorridas, especialmente no estado de São Paulo, em razão da Lei de Terras de 1850 e do avanço do complexo cafeeiro. Ao analisar a região de Ribeirão Preto, a autora argumenta que a comprovação da posse da terra realizada pelos proprietários rurais acontecia por meio de um documento expedido pela Igreja Católica, mediante a doação de uma gleba de terra para o santo padroeiro. A pesquisadora explica que por traz do movimento de fundação de cidades nesta região estava na verdade a legitimação da posse da terra. Daí se pode entender a grande quantidade de cidades que surgiram após a Lei de Terras de 1850, a partir de doações feitas por famílias às ordens religiosas, que passaram a administradoras dos dotes doados aos santos de devoção, "numa clara troca de favores" (Silva, 2008b, p. 49).

João Antônio de Paula revela que o fracasso do reformismo conservador na reestruturação fundiária durante o regime Imperial, de que resultou a permanência do latifúndio, expressou a ausência de efetiva hegemonia dos segmentos modernizantes das elites brasileiras, que foram incapazes de generalizar para o país as instituições típicas da economia de mercado sintetizadas na transformação da terra e da força de trabalho em mercadorias. A efetiva imposição dos mercados de terras e de trabalho segundo o modelo capitalista não teve dimensão nacional durante o período imperial, estando particularmente vinculada à expansão cafeeira em São Paulo, sobretudo a partir dos anos de 1880 (Paula, 2012, p. 197-198).

A Lei de Terras, na realidade, mostrou a inaptidão do governo Imperial em aprovar ou implementar medidas contrárias aos interesses dos proprietários rurais na ausência de pressões descomunais, como foi a ameaça externa ou a pressão do Poder Moderador. Mas ela mostrou também a incapacidade de estabelecer unidade da classe proprietária.

A pesquisadora Emília Viotti da Costa resumiu o indispensável da Lei de Terras em quatro aspectos básicos: o primeiro se refere ao acesso às terras públicas, que seria dado apenas pela compra; o segundo se refere ao tamanho das posses, pois sobre as terras apropriadas mediante ocupação, o limite de tamanho seria igual ao da maior doação feita na freguesia ou povoação em que se localizavam; o terceiro contemplava que o produto da venda das terras seria usado para financiar a vinda de imigrantes para o Brasil; e o quarto se refere à criação da Repartição Geral das Terras Públicas, para administrar o processo e promover a política de imigração. Assim, quando a terra se tornou uma mercadoria adquirida por indivíduos, as decisões tomadas quanto à sua utilização passaram a ser tomadas por esses mesmo indivíduos (Costa, 2010a, pp. 171-183).

A eficácia e as consequências da Lei de Terras devem ser relativizadas. A historiografia argumenta que, na prática, houve um bloqueio à discriminação das terras públicas e privadas pelos grandes latifundiários políticos, já que tal fato pressupunha um cadastro das terras ocupadas.

O historiador Raymundo Faoro, sempre com uma perspectiva singular da história nacional, considera que a referida lei sobre a política de terras devolutas não obteve o rumo expansionista do latifúndio. Para ele, ela reforçou, à margem das sesmarias, algumas posses de grande extensão. Ela frustrou diretamente a repartição da propriedade e sua limitação ao cultivo e à moradia do trabalhador da lavoura; correspondia, antes, à tendência político-econômica dos meados do século XIX, "desenfeudando" a propriedade ao comercializá-la com a redução do valor monetário, tornando-a transmissível e alienável. Raymundo Faoro ainda argumenta que a grande propriedade não é hostilizada por ser uma grande propriedade, mas por ser proveniente do Estado, que regula o crédito e pede garantias. 0 proprietário senhor de rendas cede lugar ao empresário, com a conta corrente de crédito e débito amalgamada à cidade, que está localizada no centro do Império. Esse movimento, portanto, que avassala a sociedade e domina a lei, tem o mesmo conteúdo da abolição dos morgadios em Portugal. A intenção era combater o fantasma feudal: o corpo aristocrático (Faoro, 2012, pp. 468-469). 
Entretanto, José de Souza Martins pondera que mais valiosos que a terra eram os escravos, pois o que tinha valor era o bem sujeito a comércio, o que, com a terra, ocorria apenas limitadamente. 0 autor acrescenta ainda que os mecanismos reguladores da organização econômica da fazenda não dependiam da oferta e procura dos bens por ela produzidos, fossem eles o café ou a cana de açúcar, mas da oferta e procura de trabalhadores escravos. Assim, o principal capital do fazendeiro estava investido na pessoa do escravo, imobilizado como renda capitalizada. 0 que o fazendeiro comprava quando adquiria um escravo era, na verdade, sua capacidade de criar riqueza (Martins, 2004, p. 26).

Ao analisarmos os estudos realizados sobre a região de Ribeirão Preto, interior do estado de São Paulo, quanto aos aspectos territoriais, sociais, políticos e econômicos, observamos que, a partir dos anos de 1850, essa região apresentou um processo de valorização das terras. Essa conjuntura não significou apenas uma fase de transição, mas a consolidação e a permanência da agricultura e, especialmente, da economia cafeeira nesse território. Essa fase agrícola foi, sem dúvida, estimulada pelo investimento de capitais antes mobilizados na compra e sustento dos escravos.

Lucila Reis Brioschi, Carlos de Almeida Prado Bacellar e outros pesquisadores, num trabalho conjunto sobre as terras da região de Ribeirão Preto, apontam que os escravos em plena fase produtiva, entre os 15 e 40 anos, eram os mais caros. Os pesquisadores revelam que, no decênio de 1850, com o valor de um escravo podiam-se comprar, no território de Ribeirão Preto, mais de 160 hectares de terras. No período seguinte, com o preço de um escravo mais de 300 hectares poderiam ser adquiridos. A partir daí, os preços dos cativos declinaram com muita rapidez. Comparativamente, de 1850 a 1869, o preço médio do hectare elevou-se muito menos do que o do escravo. Entretanto, a partir deste momento, enquanto a tendência do preço médio do hectare era de alta, a do preço do escravo era de queda acentuada. Apesar disso, um escravo ainda valeria mais do que 170 hectares na década de 1870 e pouco mais de 90 hectares no decênio de 1880 (Brioschi \& Bacellar, 1991, p. 238).

Como se pode compreender, o escravo era um elemento de alto valor no conjunto dos bens de um fazendeiro. Todavia, sem essa mão de obra fundamental, as terras tenderiam a permanecer incultas e improdutivas. Com a abolição da escravatura, os capitais que até então eram empregados na compra do cativo passaram a ser liberados para investimentos na terra, nas criações, na implantação e aperfeiçoamento do complexo cafeeiro e na compra de maquinários e demais equipamentos para as atividades da lavoura do café.

A pressão exercida pelo café promoveu alterações significativas no funcionamento do mercado fundiário. Sob uma visão geral, a ocupação e exploração da terra fundavam-se na monocultura, uso para a subsistência e criação de gado, no contexto de uma economia em processo de capitalização. 0 café, ao necessitar das terras de matas virgens, causou significativas alterações nos padrões de ocupação territorial e, consequentemente, nos preços da terra, valorizando lotes que, até então, permaneciam pouco explorados.

Ao analisar as transformações do mercado de terras no território da região de Ribeirão Preto, Carlos de Almeida Prado Bacellar argumenta que, para o pequeno lavrador, herdeiro de uma ou mais gerações, a implantação do café era extremamente difícil. Segundo o autor, muitos chegaram a plantar pequenas lavouras de café, mantidas com mão de obra familiar, mas com poucas chances de enfrentar a concorrência dos grandes produtores. Mesmo quando dispunham de grandes extensões de terras, a baixa capitalização do pequeno lavrador não lhe permitia vislumbrar muitas perspectivas diante da nova lavoura. A derrubada das matas para aproveitamento das terras roxas era uma operação lenta e custosa, requerendo a disponibilidade de um número expressivo de mão de obra. A cultura do café era até então trabalhosa e, acima de tudo, cara, pois produzia grãos somente a partir do quarto ano após o plantio. Era quase sempre inevitável a pressão econômica e política pela expulsão desse pequeno produtor. 0 autor revela ainda que a historiografia e a literatura sobre a cultura desse grão apontam casos em que essa pressão se fazia de forma violenta, com a utilização de homens armados para assustar os pequenos lavradores instalados nas terras desejadas. Essa violência, implícita ou explícita, não aparecia de maneira formal junto aos inúmeros atos de transação de terras envolvendo partes com poderes econômicos bastante desiguais. A explosão dos preços da terra comprova a grande superioridade econômica da nova produção agrícola (Bacellar, 1999a, p. 110). 
A introdução da ferrovia em São Paulo a partir da década de 1860 contribuiu de modo crucial para o sucesso da agricultura cafeeira. Com a ferrovia, foi possível alcançar terras mais distantes do porto exportador de Santos, graças à diminuição do custo do frete por tonelada transportada.

A Estrada de Ferro Mogiana, fundada em março de 1872, buscou atender toda a extensão territorial da região de Ribeirão Preto, até então quase totalmente à margem da economia cafeeira. Rapidamente, a Mogiana cobriria toda esta região. No ano de 1875, já havia alcançado as cidades de Mogi Mirim e Amparo, partindo da cidade de Campinas. A cidade de Casa Branca seria a próxima seção alcançada pela Cia. Mogiana, inaugurada em janeiro de 1878. Segundo o contrato celebrado com o governo da província paulista para a construção da linha até Casa Branca, a companhia foi autorizada a construir um ramal que, partindo do ponto que se julgasse mais conveniente, chegasse até os municípios de São Simão e Ribeirão Preto (Bacellar, 1999b, p. 120).

Analisando o percurso da Companhia Mogiana na região de Ribeirão Preto (Figura 1), o trecho partindo de Ribeirão Preto, após cruzar o rio Pardo, bifurcava-se na estação do entroncamento. Para a esquerda, no ramal de Santa Rita de Cássia, atual cidade de Igarapava, direcionava-se para Jardinópolis (1899), Sales Oliveira (1900), Orlândia (1901), São Joaquim da Barra, Guará, Ituverava e Igarapava, alcançando o rio Grande. 0 tronco, seguindo mais a leste, seguia para Brodowski, Batatais (1886), Franca (1887), Pedregulho e, por último, Rifaina, ainda não representada no mapa abaixo de 1898, aproximadamente, até atingir o porto Jaguará no rio Grande.

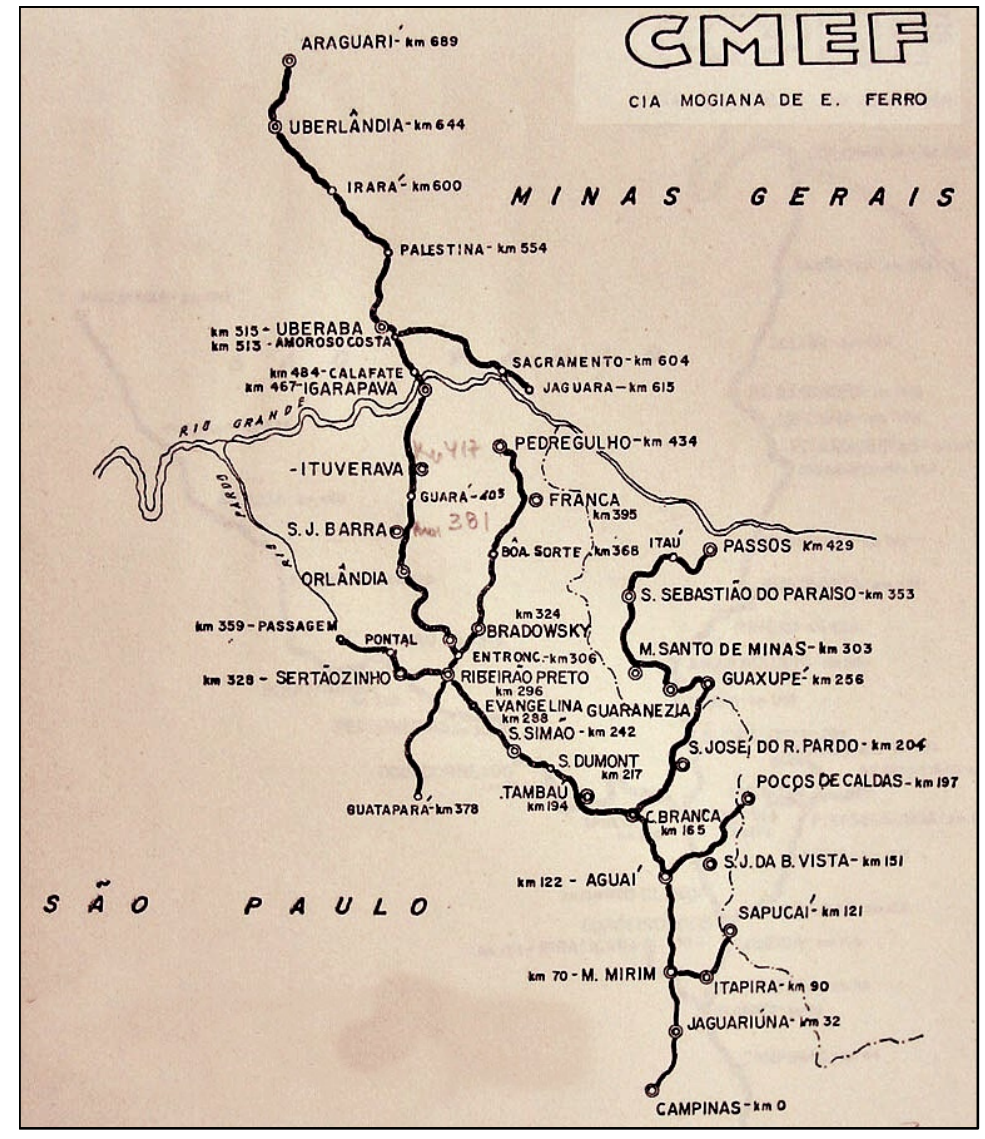

Figura 1. Mapa da Companhia Mogiana de Estrada de Ferro, 1898. Destacamos neste mapa a cidade de Ribeirão Preto e a partir dela identificamos as cidades que formavam a sua região de influência dentro dos limites territoriais paulista.

Fonte: http://vfco.brazilia.jor.br/ferrovias/ mapas/1970dnef/1970ciaMogiana.jpg

Em torno dessas estações pioneiras surgiram aglomerados de prestadores de serviços relacionados ao embarque de café e diversos pequenos comerciantes, que visavam a atender à população que, forçosamente, passaria a frequentar esse novo ponto de referência. Muitas dessas estações estão na origem de diversos centros urbanos da região em estudo, tais como Cravinhos, Orlândia, Brodowski, São Joaquim da Barra, Aramina, Pedregulho, Guará, Pontal, Sales Oliveira e Cristais Paulista.

A cidade de Ribeirão Preto foi fundada em 1856, mediante a doação de terras, por parte de alguns proprietários rurais, a São Sebastião, santo padroeiro escolhido pelos moradores à época. 
A partir deste ano começou a se configurar o povoado no ponto mais alto entre os ribeirões do Retiro e Preto, onde foi construída uma capela provisória. Com a nomeação do novo fabriqueiro 8 em 1859, Manoel Fernandes do Nascimento, este foi responsável pela demarcação do largo, assim como também pelos traçados dos arruamentos do novo povoado. Conquanto, o desenvolvimento urbano significativo teve início apenas no último quartel do século XIX, com a chegada do café.

Atendendo aos fazendeiros, comerciantes e exportadores de café, os trilhos da Companhia Mogiana alcançaram Ribeirão Preto em 23 de novembro de 1883. Juntamente com a estrada de ferro, foi construída uma estação provisória. Porém, os vereadores ficaram descontentes com a localização, por se encontrar longe do núcleo urbano principal e próximo ao leito do córrego, em uma área de constantes alagamentos. Dessa forma, a Companhia Mogiana sentiu-se forçada a construir uma nova estação no ano de 1885. O movimento desenvolvido pelos vagões da Companhia abriu novas perspectivas para a então Vila de Ribeirão Preto. Através do "ir e vir" dos comboios, não somente embarcavam as toneladas de café com destino a Santos e daí para a Europa, como também, no sentido inverso, esses vagões chegavam lotados de imigrantes destinados ao trabalho nas plantações de café.

Dentro desta perspectiva é criado em 1887 o núcleo colonial Antônio Prado, implantado em terras devolutas disponíveis em Ribeirão Preto. A proposta era que ele servisse como repositório de mão de obra para as fazendas da região, atendendo às exigências do complexo de atividades que envolvia a produção cafeeira. Segundo o Departamento de Patrimônio da União, a regularização do patrimônio do referido núcleo foi proveniente do confisco pelo Governo Imperial de terras da Fazenda "Ribeirão Preto abaixo" ao tenente-coronel Gabriel Garcia de Figueiredo, em 1878 (Silva, 2008b, p. 56).

O núcleo colonial Antônio Prado foi beneficiado pela Lei de 1884, segundo a qual o governo Imperial autorizava o governo provincial a estabelecer cinco núcleos coloniais nos principais distritos agrícolas que se encontravam próximos das estradas de ferro; através da Companhia Mogiana de Estrada de Ferro, que já fazia o transporte de café para o porto de Santos e chegava com os imigrantes, a produção do núcleo Antônio Prado poderia ser distribuída para os mercados regionais, fato que contribuiu para seu desenvolvimento. Segundo Adriana Capretz Borges da Silva, fundamentado na referida lei, em 1887 o Ministério da Fazenda colocou à disposição do Presidente da Província a quantia de $\mathrm{R} \$ 5: 000 \$ 000$ (cinco contos de Rés) para aquisição de terras para a formação do Núcleo Colonial Antônio Prado (Silva, 2008b, p. 56). No ano de 1886 foram mapeados os "terrenos nacionais9" em Ribeirão Preto (Figura 2).

O Núcleo Antônio Prado foi dividido em exatos 200 lotes dispostos em cinco partes, sendo quatro seções e a sede (Figura 3). Internamente, os limites das seções coincidiram com as barreiras naturais e artificiais já existentes: em primeiro lugar, a estrada de ferro Mogiana, ao lado do Ribeirão Preto, dividiu o Núcleo ao meio. Ao leste do ribeirão, o limite entre a Terceira e Quarta Seção era demarcado pela estrada para Batatais. A oeste do ribeirão, a Sede constituía a menor área, limitando-se com a Primeira Seção através do início da via de acesso à Cidade e com a Segunda Seção, a maior de todas (Silva, 2008b, p. 59).

A partir da inauguração, começaram a ser feitos os pedidos de lotes por parte dos colonos, sendo que alguns imediatamente obtiveram de pronto a concessão. Para adquirir um Título Provisório, deveria ser redigido um requerimento ao Presidente da Província de São Paulo, em que o candidato deveria identificar-se e justificar seu pedido. 0 Núcleo Antônio Prado, assim como os demais núcleos coloniais criados no país, tinha o objetivo de abastecer a cidade com gêneros de subsistência, podendo até mesmo fornecer eventual mão de obra a lavoura cafeeira, entretanto, o que se observa, em Ribeirão Preto, que o Núcleo serviu para "esconder tudo o que a elite emergente desejava afastar de seu convívio" (Silva, 2008b, p. 75).

\footnotetext{
${ }^{8}$ Fabriqueiro era o membro do conselho paroquial responsável por recolher os rendimentos de uma Igreja e administrar o patrimônio da mesma. Para o conselho paroquial tudo que gerava renda deveria ser considerado "fábrica", incluindo as porções de terras aforadas.

${ }^{9}$ Os terrenos nacionais eram terras cujas posses ou cultivo não foram reconhecidos após a Lei de Terras de 1850 para a aquisição do Título de Propriedade e passaram a pertencer ao Governo Imperial.
} 


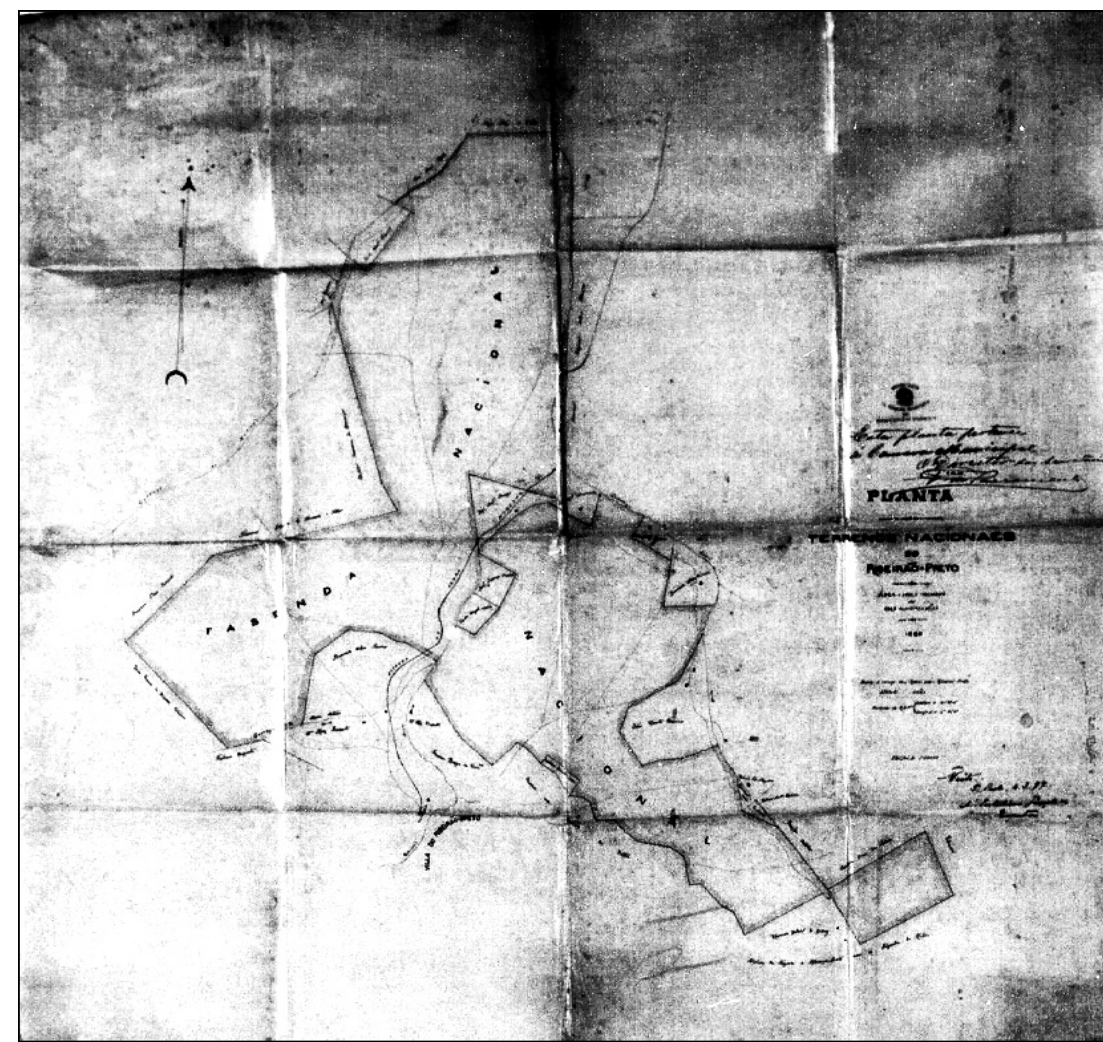

Figura 2. Planta dos terrenos nacionais em Ribeirão Preto, 1886. Nesta Figura através da mancha laranja interpretamos a localização da Vila de Ribeirão Preto.

Fonte: Arquivo Público e Histórico de Ribeirão Preto.

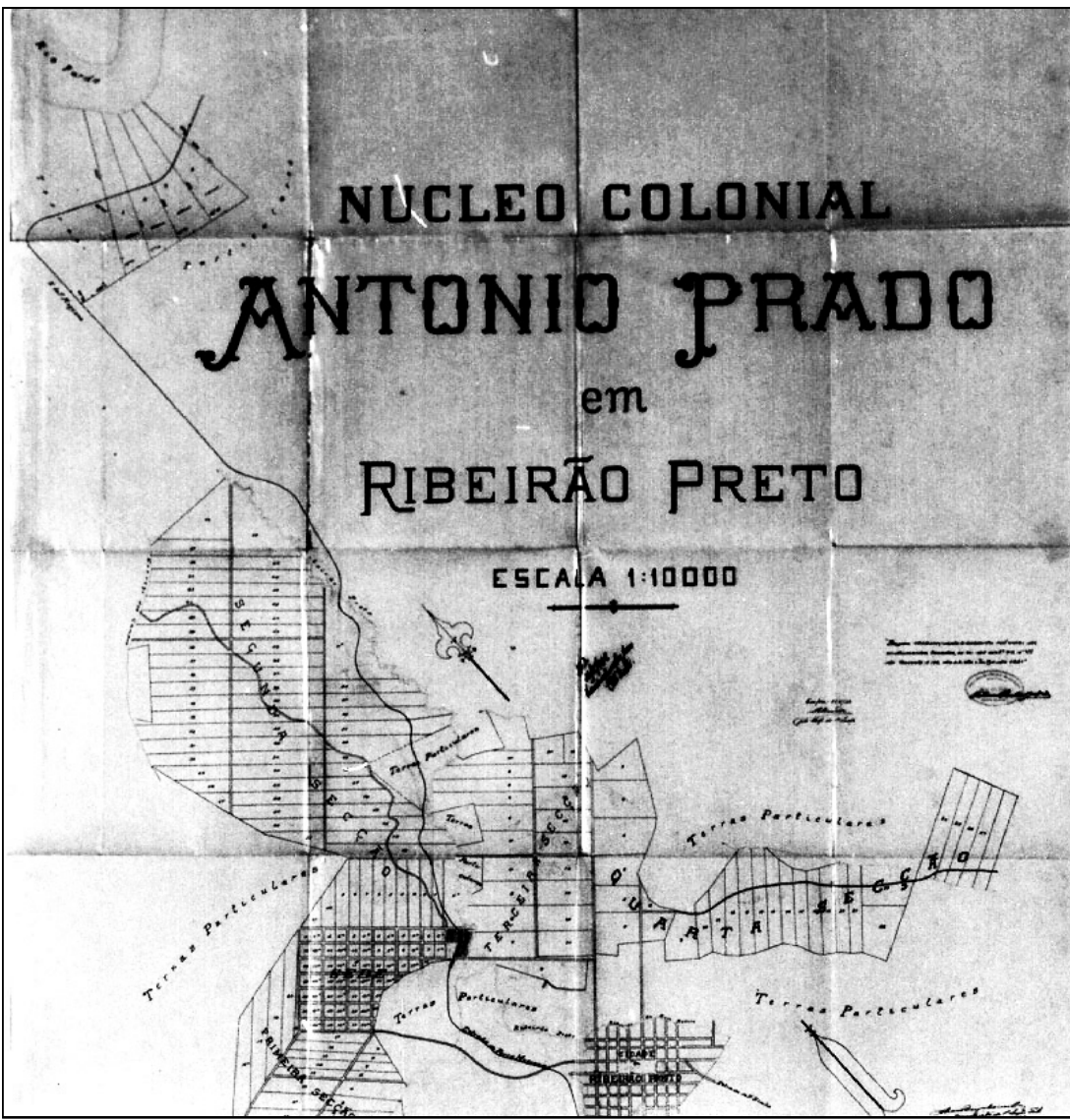

Figura 3. Planta do Núcleo Colonial Antônio Prado em Ribeirão Preto, 1932. Na mancha laranja destacamos o patrimônio fundiário religioso de fundação da cidade de Ribeirão Preto.

Fonte: Arquivo Público e Histórico de Ribeirão Preto.

As cidades localizadas no trajeto das ferrovias conheceram prosperidade, sobretudo aquelas que se encontravam em suas linhas-tronco. Ana Luiza Martins comenta que, por algum tempo, desfrutaram da posição de cidades "fim de linha", ou de local de baldeamento de passageiros, até que a parada seguinte atraísse novos serviços e mais população para servir ao café. Muitas dessas estações funcionaram como portos secos para a expedição do produto, implantados em 
entroncamentos estratégicos para o seu despacho. As cidades que ficavam à margem da linha ou do traçado da ferrovia, passaram inevitavelmente por uma decadência (Martins, 2009, p. 174). Progresso e decadência foram duas faces de uma mesma moeda.

No entanto, o que nos interessa neste item é entender a nova dinâmica da terra urbana. Norma Regina Truppel Constantino, quando estudou a estrutura agrária na formação de espaços urbanos no oeste paulista, expressou que a estrada de ferro foi o que determinou o eixo de crescimento urbano, independentemente de qual fosse a linha. A autora estava analisando as formações urbanas à margem das linhas férreas Alta Paulista, Araraquarense, Noroeste e Sorocabana, ou seja, no oeste paulista. Elas foram fundamentais para a fixação do povoamento e para o desenvolvimento dessas regiões, já que a chegada dos trilhos valorizava os terrenos, fazia o comércio se desenvolver e atraía cada vez mais novos desbravadores (Constantino, 2010, p. 35).

Segundo a autora, no oeste paulista, em função do processo de implantação da rede ferroviária ser de período mais recente, o patrimônio religioso não figurou na formação das cidades. 0 loteamento privado da terra foi observado na maioria das cidades dessa parte do estado paulista. Essa política poderia ser desempenhada ora pelos grandes fazendeiros, ora por empresas de loteamento. A base do sucesso do empreendimento dos novos núcleos urbanos era a publicidade feita em torno de um patrimônio laico (Constantino, 2010, p. 35).

A cidade proporcionava oportunidades para todos, mas especialmente para os que chegassem primeiro, isto é, os pioneiros, e sua fundação tinha duas motivações básicas: lucro e poder. Como o objetivo maior constituía em obter rápido retorno do investimento feito, vender as terras tornou-se uma fonte de recursos menos incerta e mais rentável para os loteadores privados. Para que o negócio fosse lucrativo, era preciso organizar o espaço (Constantino, 2010, p. 44). Assim, os patrimônios laicos urbanos criados sob essa conjuntura assumiram a tipologia do traçado ortogonal. A partir dessa racionalidade, o fazendeiro ou a companhia já tinham em registro o número certo de lotes e definido o valor de cada um; anotava-se, ao final, o lucro total com o comércio da terra urbana.

Pierre Monbeig revela que o traçado dos lotes rurais foi o mesmo em toda parte e, seguramente, foi o mais fácil e o menos oneroso no trabalho do loteador. 0 acesso à agua e ao espigão foram elementos importantes neste processo. Para o autor cortava-se as vertentes de cada um dos pequenos vales em faixas perpendiculares aos ribeirões, todas com aproximadamente a mesma superfície. Nas partes altas dos vales, nas cabeceiras, os lotes foram talhados obliquamente e dobrados em cotovelo na sua parte inferior (Monbeig, 1984, p. 221). Sobre os lotes urbanos, o autor descreve que a organização de um patrimônio urbano acontecia na faixa mais ou menos estreita do planalto, sempre, porém suficiente para comportar uma cidade, com os suaves declives dos vales que neles nascem, declives bastante para o escoamento das águas de esgoto e de chuva. Não havia como prever nestes terrenos os trabalhos de terraplenagem. Repete-se incansavelmente o plano geométrico, pois é o que melhor satisfaz as exigências do loteador, assim como as condições topográficas. A regularidade é uma constante em razão da ideia de lucro a ser obtido. Cada cidade é, portanto, uma réplica da cidade vizinha (Monbeig, 1984, p. 342-346).

Analisando as cidades formadas à beira da linha, também no oeste paulista, Nilson Ghirardello afirma que, no processo de formação urbana, ao iniciar o arruamento desses povoados, o arruador foi tomado por base, em todos os casos, a longa reta originada pela linha da ferrovia, ou até mesmo os limites de divisa da esplanada da estação. Verifica-se que a ferrovia, além de possibilitar a vida econômica ao futuro povoado, garantindo acessibilidade e escoamento da futura produção, gerou o próprio desenho urbano. Destaca o autor que, outra condição favorável para a formação dos núcleos à margem de uma estação foi a proximidade da água (Ghirardello, 2002, pp. 170-171).

Dentro da extensão territorial da região de Ribeirão Preto, apontamos duas cidades que expressam uma parte desse processo de formação do loteamento a partir de um patrimônio laico, são elas: Cristais Paulista (1895) e Orlândia (1902). A primeira surgiu do desejo do cafeicultor Alexandre Vilella de Andrade. 0 desenho dessa cidade ficou a cargo do engenheiro agrônomo Luiz Rodrigues Nunes, formado na Imperial Escola Agrícola de São Bento das Lages, estado da Bahia. 0 traçado foi pensado sob a forma de quadras uniformes, medindo $80 \mathrm{~m}$ por $80 \mathrm{~m}$, formadas por oito lotes 
regulares de $20 \mathrm{~m}$ por $40 \mathrm{~m}$, ficando o espaço de uma das quadras reservado para a praça da cidade (Figura 4). A segunda, Orlândia, surgiu pelo desejo do coronel Francisco Diniz Junqueira, que designou o engenheiro civil Luiz de Mello Marques, formado na Escola Politécnica do Rio de Janeiro, para elaborar o traçado da nova localidade; ruas e avenidas largas delineadas na forma de um "tabuleiro de xadrez" foram idealizadas para a cidade (Figura 5) (Salgado \& Piccinato Junior, 2011, pp. 1-20).
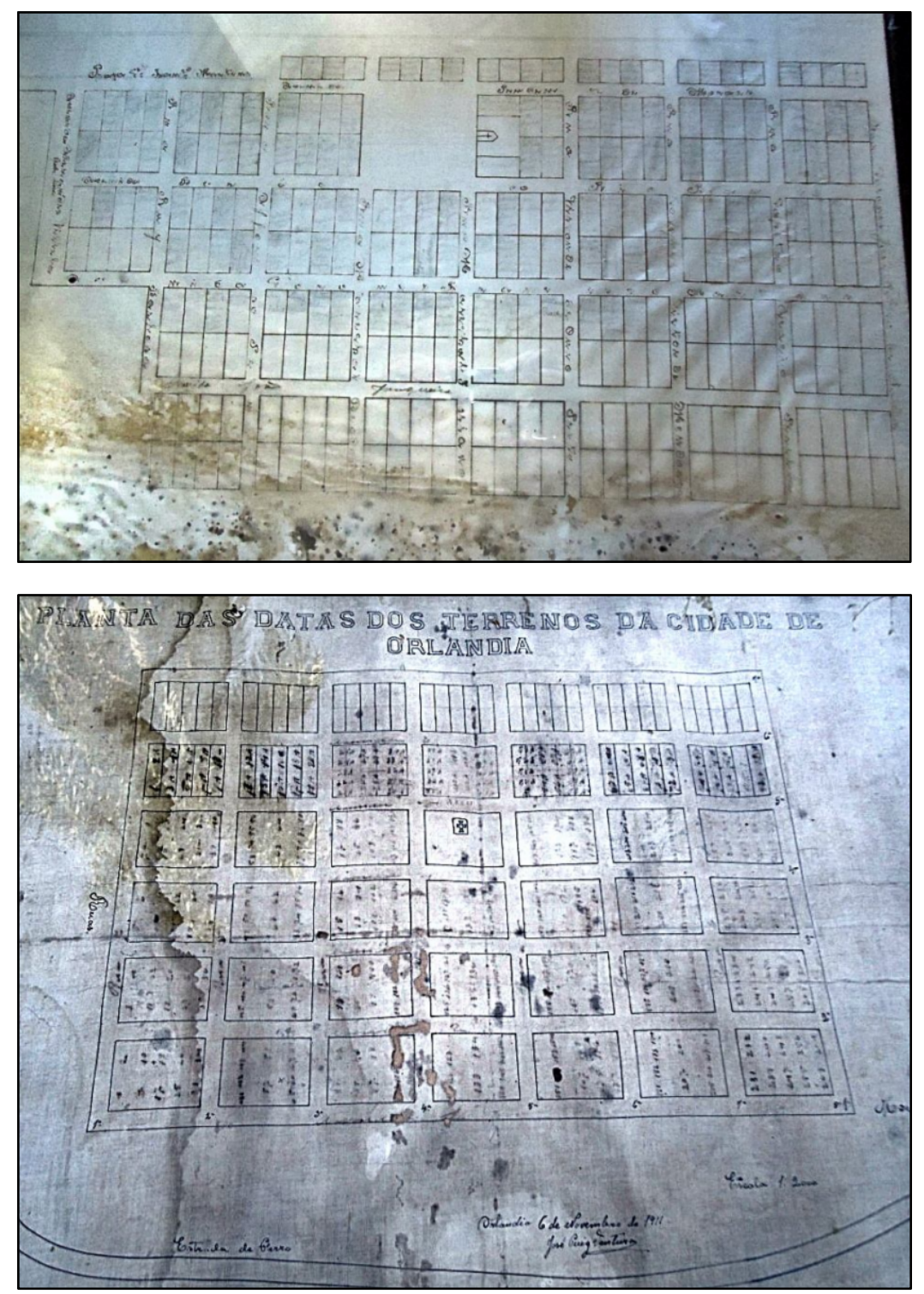

Figura 4. Projeto urbano elaborado por Luiz Rodrigues Nunes para Cristais Paulista.

Fonte: Salgado; Piccinato Junior, 2011, p. 9.

Figura 5. Planta de 1911 das "datas dos terrenos" de Orlândia (SP) elaborada por José Luiz Ventura, a partir do projeto urbano do engenheiro Luiz de Mello Marques. Fonte: Salgado \& Piccinato Junior, 2011, p. 15.

Em suma, a cidade que se (re)constrói no século XIX, como nos revela Guido Zucconi, parece ter sido dominada pelos fatores dinâmicos (Zucconi, 2009, p. 14). A indústria, as exposições universais, os sistemas de comunicação e deslocamento, as ideologias urbanas, os novos equipamentos urbanos, são alguns exemplos que determinaram o caráter dinâmico para o urbano.

Completando a ideia dos elementos dinâmicos revelada por Guido Zucconi, no espaço urbano laicizado, argumenta Ana Luiza Martins, os artefatos representativos das transformações do capital, dos novos grupos sociais delineados e da evolução urbana da cidade paulista, analisada pela autora, emergiu com outra carga de significação. Ao lado da Igreja Matriz e da Casa de Câmara e Cadeia, evocativas de um tempo religioso não tão distante, figuravam confirmando o tempo secular e a "dessacralização do espaço", inúmeras casas de comércio, hotéis, agências bancárias, escolas públicas, templos protestantes, unidades fabris, bairros operários etc. Nessa rede urbana que emergia quase que de repente, a sombra do café, uma nova sociedade, com grupos sociais diferenciados, exercitava-se em momentos de ajuste e ordenamento, procurando descortinar caminhos e novos espaços (Martins, 1994, p. 186-187). 
As cidades da segunda metade do século XIX foram marcadas pelo progresso técnico. Profissionais eruditos das engenharias e áreas afins formaram o corpo técnico da disciplina do urbanismo e se tornaram símbolos do poder do conhecimento.

A ampliação do papel da mão de obra livre como sustentáculo das fazendas de café promoveu novas formas do trabalho. As senzalas foram progressivamente substituídas pelas colônias, onde foram instaladas as famílias de camponeses europeus e de migrantes nacionais. Com a extinção do trabalho forçado, novos direitos e deveres foram estabelecidos, caracterizando o contrato de trabalho que ficou conhecido como colonato.

Carlos de Almeida Prado Bacellar explica que o modelo de contrato que vigorou nas fazendas cafeeiras a partir dos anos de 1880 foi o colonato, um sistema misto de remuneração por tarefa e por medida colhida pelo colono. 0 fazendeiro responsabilizava-se pelos gastos do trabalhador durante seu primeiro ano na fazenda e cedia um pedaço de terra para que o colono pudesse cultivar sua roça para subsistência. Era também permitido ao colono o usufruto das linhas de terras formadas pelas ruas dos pés de café, bem como a criação de alguns animais, como galinhas, porcos e, conforme a dimensão da fazenda, vacas e cavalos. A venda do excedente de suas roças e da sua criação complementava o ganho do colono, proveniente do seu trabalho na lavoura cafeeira. Assim, o colonato se caracterizou pela combinação de três elementos essenciais: pagamento fixo pelo trato do cafezal, pagamento proporcional pela quantidade de café colhido e produção direta de alimentos para sustento próprio e comercialização do excedente. A remuneração, apesar de estabelecida anualmente, era dada todos os meses no primeiro sábado de cada mês, pois este era o dia de folga para que os colonos realizassem suas compras e demais atividades da família (Bacellar, 1999b, p.147).

Os trabalhadores de origem estrangeira constituíram o grosso da mão de obra na fazenda cafeeira, complementada por trabalhadores temporários, especializados e administrativos. Para o fazendeiro, o colonato era mais lucrativo que o trabalho assalariado simples, pois as roças de subsistência lavradas pelos colonos reduziam o custo da mão de obra. Outra estratégia adotada pelos fazendeiros para reduzir os custos foi dar preferência para as grandes famílias imigrantes, pois, quanto maior fosse o número de trabalhadores, menor seria o custo de produção do trabalhador individual.

O que observamos é que, se, no regime escravocrata, os recursos investidos na compra de escravos representavam a parcela principal do capital da fazenda, no regime de trabalho livre a parcela principal do capital era investida no cafezal. Segundo José de Souza Martins, esse capital tinha, pois, uma clara procedência não capitalista. A propriedade capitalista da terra assegurava ao fazendeiro a sujeição do trabalho e, paralelamente, a exploração não capitalista do trabalhador. Com base no monopólio sobre a terra, o fazendeiro de fato não empregava o construtor do cafezal. Na prática, ele lhe arrendava uma porção do terreno para receber em troca o cafezal já formado. Uma espécie de "renda-em-trabalho". Podemos considerar, portanto, que não era o fazendeiro quem pagava ao trabalhador pela formação do cafezal. Era o próprio colono quem pagava com cafezal ao fazendeiro pelo direito de usar as mesmas terras na produção de alimentos durante a fase de formação do cafezal. Assim, a principal forma de capital absorvida na formação da fazenda de café era o trabalho, que se convertia diretamente em capital permanente, o cafezal. 0 autor considera, complementando a ideia, que "a fazenda produzia, a partir de relações não capitalistas de produção, grande parcela do seu próprio capital." (Martins, 2004, p. 74).

Na nova ordem republicana, política, sociedade e cultura se entrelaçam com os cafezais. Ao longo da Primeira República, particularmente, conjugam-se o surto econômico advindo daquela monocultura e a construção de uma classe dirigente, que contemplou modelos políticos e projetos de hegemonia formados à sombra dos cafezais.

Outro aspecto interessante neste momento do Brasil republicano são as medidas adotadas pela Igreja Católica com o objetivo de resguardar aquilo que havia conquistado. A Igreja e o Estado mantiveram uma união que perdurou entre o Brasil Colonial e Imperial. Com a Proclamação da República o Estado tonou-se laico. A Igreja receosa de perder o que havia conquistado impõe uma política centralizadora em terras nacionais. Dentre uma das medidas destaca-se a divisão de várias regiões do país em dioceses, numa clara alusão a ideia de dividir para centralizar. No ano de 1908 é formado o Bispado de Ribeirão Preto composto pela cidade sede (Ribeirão Preto) e 
mais 46 cidades vizinhas, aproximadamente. D. Alberto José Gonçalves, o primeiro bispo do bispado recém-formado, personificando a política centralizadora da Igreja Católica entre os anos de 1909 e 1913 faz uma série de visitas às cidades que integravam o bispado com o intuito de verificar as reais condições dos patrimônios fundiários aforados às igrejas locais. A intenção do bispo era a de defender os interesses e bens da Igreja Católica, destacando que a terra aforada era fonte de rendimentos para a Igreja (Piccinato Junior, 2016).

Apresentamos como exemplo deste movimento da Igreja em defesa de seus bens a cidade de Ribeirão Preto. 0 patrimônio fundiário original de fundação da cidade ainda hoje pertence a São Sebastião, santo de devoção e para quem a terra foi doada. A Igreja local é a "tutora" dos bens do santo. No ano de 1932 a Igreja de Ribeirão Preto contratou o engenheiro Antônio Soares Romeo para fazer o mapeamento das quadras da cidade em regime de aforamento (Figura 6). Recentemente, em 2016, em nossa tese de doutorado procuramos revelar os aspectos morfológicos da terra aforada de Ribeirão Preto ao analisar os pedidos de aforamentos de lotes entre os anos de 1928 e 1931, revelando a transformação da terra urbana em mercadoria (Piccinato Junior, 2016, p. 260).

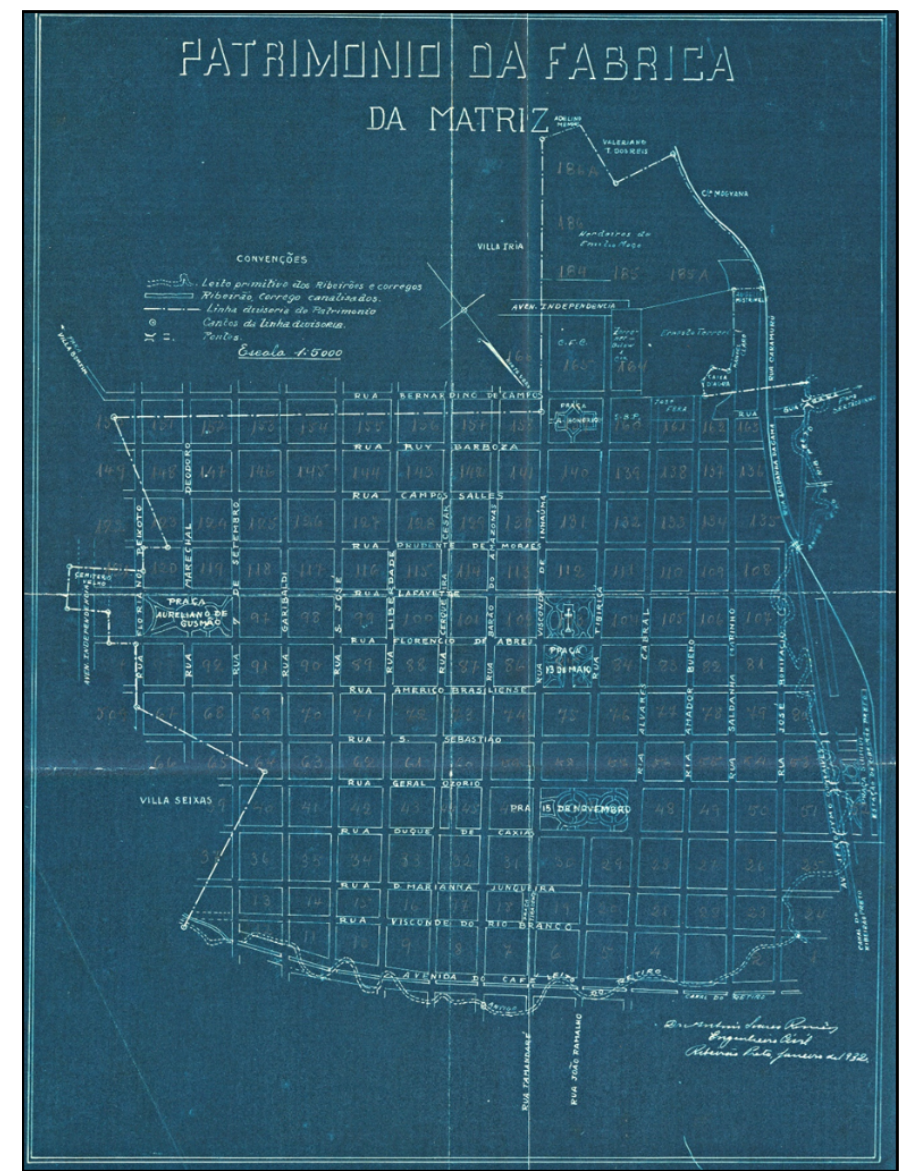

Figura 6. Mapa do patrimônio da "Fabrica da Matriz" de Ribeirão Preto, 1932. Fonte: Arquivo Público e Histórico de Ribeirão Preto.
Na década dos anos de 1890, o Brasil produzia cerca de $70 \%$ do café mundial, o que lhe permitia exercer considerável influência na oferta. Diretamente, a produção cafeeira sustentava a economia nacional. Entre os anos de 1890 e 1910, o número de pés de café no estado de São Paulo aumentou significativamente, configurando nestas terras o grande foco de produção no país. Naquela altura, último quartel do século XIX, não havia muito o que se preocupar com os concorrentes. 0 cenário era próspero. As ferrovias otimizavam o transporte do produto e as terras roxas qualificavam a mercadoria.

Conquanto, no século XX, o problema de superprodução permaneceu e se agravou. Ao longo dos últimos anos, a produção nacional havia triplicado. Para garantir o lucro das safras e evitar a queda do preço, a primeira estratégia foi a de estabelecer um plano oficial de valorização do produto: o Convênio de Taubaté. Este acordo estabeleceu que deveria haver um preço mínimo para a saca de café; propôs intervenção estatal no mercado, comprando o excedente com a intenção de retirar do mercado uma boa parte do produto para restabelecer o equilíbrio entre oferta e procura; definiu política de financiamento dessas compras a partir de empréstimos de capitais estrangeiros; idealizou a negociação de um empréstimo externo; procurou estabelecer a amortização e juros desses empréstimos; definiu o estabelecimento de um fundo para a estabilização do câmbio e, por fim, impôs uma taxa proibindo o plantio de novas áreas de café. Apesar da urgência, essas medidas não foram implementadas de pronto. $\mathrm{A}$ crise persistiu (Martins, 2009, pp. 224-229).

A história nos revela que outras intervenções foram feitas, mas a crise de 1929 foi a que realmente deixou marcas. A crise da bolsa não veio sozinha. Na sequência também veio a Revolução de 1930 com a subida de Getúlio Vargas ao poder. Nesse contexto, as relações de trabalho e poder no campo também experimentaram mudanças; foi quando imigrantes puderam conhecer uma primeira ascensão, fosse atingindo o degrau de pequeno proprietário ou conseguindo enriquecimento por meio da diversificação e especulação do capital agrícola.

(C) Labor \& Engenho, Campinas [SP] Brasil, v.11, n.3, p.335-354, jul./set. 2017. 
A crise de 1929 pode também ser vista como marco da fragmentação do latifúndio cafeicultor. A partir dela, intensificou-se o retalhamento da terra e a pequena propriedade se revelou uma alternativa para o cultivo agrícola. Ana Luiza Martins ilustra tal conjuntura ao expor o que ocorreu no complexo cafeeiro de Franca, primeira freguesia, criada em 1804, na região de Ribeirão Preto. Ali, entre os anos de 1890 e 1914, as fazendas se instalaram com o regime de colonato. A dificuldade de cumprir os contratos de trabalho em período de dificuldades econômicas levou alguns proprietários a vender pequenos lotes de terras a colonos como forma de pagamento de dívidas. Por parte dos colonos, a possibilidade de acumulação derivava do trabalho familiar e revenda de produtos plantados nas ruas dos cafezais. Após 1929, o retalhamento se consumou, permitindo novo ordenamento não só das propriedades, mas também dos costumes, da sociedade, das práticas culturais, da paisagem (Martins, 2009, pp. 246-247).

A dialética da propriedade fundiária nos revelou que os processos de ocupação e apropriação territorial foram partes integrantes do processo de construção e consolidação do Estado brasileiro e da formação das classes. 0 papel desempenhando pela iniciativa privada (ou pública) no tocante à ocupação de terras, bem como à maneira como as políticas governamentais foram adaptando a "questão da terra" em função da pressão exercida pelas camadas predominantes no meio rural atesta a participação dinâmica da sociedade na definição das posições assumidas pelo Estado relativamente a essa questão.

O problema da terra urbana entre o Brasil Império e a Primeira República ficou condicionado às decisões das câmaras municipais e igrejas locais. A Lei de Terras de 1850 em muito pouco contextualizou as formas de gerenciamento e atuação sobre a terra urbana. Foi somente no final do século XIX, com a ideia de lucro sobre a propriedade fundiária, que a terra urbana ganhou valor por meio da constituição do patrimônio laico; todavia remanescem nesse momento cidades que foram fundadas a partir do patrimônio religioso, revelando a lógica da terra como mecanismo de posse e urbanização, aliada a interesses particulares ou coletivos.

\section{Conclusão}

Neste trabalho teve-se como preocupação central as discussões que fundamentaram a estrutura fundiária desenvolvida no Brasil entre o século XIX e as três primeiras décadas do século XX. Destacou-se que o tema tem particular interesse quando remetido ao processo de configuração e reconfiguração dos espaços urbanos, aspecto que necessita de maiores esclarecimentos quando observamos as diferentes realidades construídas no país e as diferentes relações entre os poderes municipal, estadual e federal. Lançar luz sobre as relações e dissenções entre esses poderes é fundamental para auxiliar no entendimento do Estado nacional, já que há momentos que essas três instâncias não parecem estabelecer um diálogo unívoco de interesses comum, mas representam hierarquias distintas de disputas de poder. Essas ausências de sintonia entre as diferentes dimensões de poder e a instabilidade política mostrou-se que isto teve um enraizamento cultural, em certa medida, uma característica da própria situação do Brasil Colonial.

Os aspectos históricos da construção do Brasil nos revelaram que as atuações políticas foram organizadas e estruturadas num ambiente de incertezas e o que melhor refletiu este contexto foi a propriedade fundiária. A dialética da propriedade fundiária privada caracterizou-se não só pelo rearranjo do poder, mas acima de tudo na conformação de sua estrutura depois de cada inserção normativa. Num primeiro momento as sesmarias e depois a terra como mercadoria possibilitaram na formação de um jogo de xadrez, onde o jogo de interesses entre as partes que se alternavam conferia a tônica espacial da propriedade. Considerando que no tabuleiro do jogo destacavam-se diferentes personagens que buscavam ora resguardar o que haviam conquistado, ora conquistar novas extensões ou oportunidades de novas conquistas; em síntese, o que podemos observar que em ambas as condições o que estava sendo disputado era o status quo que a política conferia ao indivíduo.

Mediante as diferentes arregimentações pela qual a política brasileira estabeleceu ao longo do tempo em relação a temática da propriedade fundiária privada, a percepção acerca da manutenção da estrutura fundiária concentrada em poucas mãos, reforçada com a implementação de políticas agrícolas, como a implantação de núcleos coloniais, por exemplo, estiveram na base de um 
processo de crescimento econômico. Esse crescimento econômico que em determinados momentos cedeu a pressões externas determinou que a organização da propriedade privada fosse gradativamente ganhando destaque a partir da mudança da mão de obra. Com a valorização da terra, urbana ou rural, institui-se um forte mercado dela. Assim sendo, o que podemos ponderar que a propriedade fundiária da terra foi a que melhor representou as diferentes instabilidades e mudanças que o Brasil sofreu durante o século XIX.

Em particular podemos considerar que o período Imperial não foi necessariamente um entreposto entre o que aconteceu no Brasil Colonial e o que veio a representar o regime republicano. Esta dimensão histórica definiu-se na reorganização política e econômica nacional, na tentativa de se construir um Estado e para construí-lo foi necessário redefinir os rumos da política fundiária. Para tanto, o que aconteceu foi uma redefinição da ideia de propriedade, com a intenção de simbolizar o caráter da terra no Brasil.

\section{Referências Bibliográficas}

Bacellar, C. de A. P. (1999a). Uma rede fundiária em transição. In C. de A. P. Bacellar \& L. R. Brioschi (orgs.). Na Estrada do Anhangüera: uma visão regional da história paulista (pp. 92-116). São Paulo: Humanitas FFLCH-USP.

Bacellar, C. de A. P. (1999b). Apogeu cafeeiro na Alta Mojiana. In C. de A. P. Bacellar \& L. R. Brioschi (orgs.). Na Estrada do Anhangüera: uma visão regional da história paulista (pp. 117-163). São Paulo: Humanitas FFLCH-USP.

Brioschi, L. R., Bacellar, C. de A. P., et al. (1991). Entrantes no Sertão do rio Pardo: o povoamento da Freguesia de Batatais século XVIII e XIX. São Paulo: CERU.

Constantino, N. R. T. (2010). A estrutura agrária na formação do tecido urbano das cidades do oeste paulista. In I. Salgado \& A. Bertoni (orgs.). Da construção do território ao planejamento das cidades - competências técnicas e saberes profissionais na Europa e nas Américas (1850-1930). São Carlos: RiMA.

Costa, E. V. da (2010). Da Monarquia à República: momentos decisivos (9a. ed.). São Paulo: Editora Unesp.

Bandecchi, B. (1972). O município no Brasil e sua função política. São Paulo: Coleção da Revista de História.

Faoro, R. (2012). Os donos do poder: formação do patronato político brasileiro (5a. ed.). São Paulo: Globo.

Fausto, B. (2015). História do Brasil (14a. ed.). São Paulo: Edusp.

Ghirardello, N. (2002). À beira da linha: formações urbanas da Noroeste Paulista. São Paulo: Editora Unesp.

Leal, V. N. (2012). Coronelismo, enxada e voto: o município e o regime representativo no Brasil (7a. ed.). São Paulo: Companhia das Letras.

Martins, A. L. (1994). A invenção e/ou eleição dos símbolos urbanos: história e memória da cidade paulista. In S. Bresciani (org.). Imagens da Cidade. Séculos XIX e XX (pp. 177-190). São Paulo: ANPUH; Marco Zero; Fapesp.

Martins, A. L. (2009). História do café. São Paulo: Contexto.

Martins, J. de S. (2004). O cativeiro da terra (8a. ed.). São Paulo: Hucitec.

Monbeig, P. (1984). Pioneiros e fazendeiros de São Paulo (A. França \& R. de A. e Silva, Trads.). São Paulo: Editora Hucitec; Editora Polis, 1984.

Moreira, Ruy (2014). A formação espacial brasileira: contribuição crítica aos fundamentos espaciais da geografia do Brasil (2a. ed.). Rio de Janeiro: Consequência.

(C) Labor \& Engenho, Campinas [SP] Brasil, v.11, n.3, p.335-354, jul./set. 2017. 
Motta, M. M. M. (2012). Direito à terra no Brasil: a gestão do conflito: 1795-1824. São Paulo: Alameda.

Paula, J. A. de (2012). O processo econômico. In J. M. de Carvalho (coord.). A construção nacional: 1830-1889 (v. II, pp. 179-223). Rio de Janeiro: Objetiva.

Piccinato Jr., D. (2016). Em chão urbano, o senhorio é santo: urbanização e aforamento de terras no Bispado do Ribeirão Preto entre o Brasil Império e a Primeira República. (Tese de Doutorado). Pontifícia Universidade Católica de Campinas, Centro de Ciências Exatas, Ambientais e de Tecnologias, Programa de Pós-Graduação em Urbanismo, Campinas, SP, Brasil.

Salgado, I., \& Piccinato Jr., D. (2011). O saber técnico de profissionais das engenharias na conformação do urbano no nordeste do Estado de São Paulo. Estudos de caso: Cristais Paulista e Orlândia. Cadernos de PósGraduação em Arquitetura e Urbanismo, 11(2), pp. 1-20. São Paulo: Mackenzie, Recuperado de: http:// editorarevistas.mackenzie.br/index.php/cpgau/article/view/ 6065

Schwarcz, L. M. (2012). População e sociedade. In L. M. Schwarcz (coord.). A abertura para o mundo: 1889-1930 (3, pp.35-83). Rio de Janeiro: Objetiva.

Silva, L. O. (2008). Terras devolutas e latifúndios: efeitos da lei de 1850 (2a. ed.). Campinas: Editora da Unicamp.

Silva, A. C. B. da (2008). Expansão urbana e formação dos territórios de pobreza em Ribeirão Preto: os bairros surgidos a partir do núcleo colonial Antônio Prado (1887). (Tese de Doutorado). Universidade Federal de São Carlos, Programa de Pós-Graduação em Ciências Sociais, São Carlos, SP, Brasil.

Zucconi, G. (2009). A cidade do século XIX (M. Barda, Trad.). São Paulo: Perspectiva. 